\title{
ЕКСПЕРИМЕНТАЛЬНЕ ДОСЛІДЖЕННЯ ПРОЦЕСУ ФОРМУВАННЯ ЕСТЕТИЧНОЇ КУЛЬТУРИ МАЙБУТНІХ УЧИТЕЛІВ УКРАЇНСЬКОЇ МОВИ І ЛІТЕРАТУРИ
}

\begin{abstract}
У статті подано результати експериментального дослідження перевірки авторської концепиії та ефективності розробленої педагогічної системи формування естетичної культури майбутніх учителів української мови і літератури в процесі їх професійної підготовки у ЗВО України та дотримання низки педагогічних умов на інституиіийному рівні. Охарактеризовано иілі та зміст основних етапів експериментального дослідження (діагностико-мотиваційний, методологічно-експериментальний, аналітико-узагальнюючий. Вказані використані під час експерименту стандартизовані й розроблені авторські методики діагностики (методика М. Рокича «Ціннісні орієнтації», методика визначення мотивації до естетичної діяльності Т. Елерса, тест-опитувальник «Діагностика рівня емпатії» I. Юсупова, тест на рефлексію (за опитувальником А. Карпова), опитувальники «Визначення рівня критичного мислення», "Сфера інтересів студентів», «Значення естетичної культури в професійній діяльності вчителя української мови і літератури», опитувальник для визначення рівня естетичного сприйняття художніх творів та їх оцінювання, інтерв 'ювання «Мої естетичні інтереси та потреби», тестування навчальних досягнень студентів). Наведені дані апробаиії педагогічної системи в досліджуваний період 2012-2019 рр., зокрема результати розподілу майбутніх учителів украйнської мови і літератури за рівнями сформованості естетичної культури на констатувальному етапі експерименту та порівняльний аналіз рівнів сформованості естетичної культури контрольних та експериментальних груп до та після завершення експерименту свідчать про доцільність застосування запропонованої педагогічної системи формування естетичної культури у ЗВО, шо готують майбутніх учителів украӥнської мови і літератури. Якщо на початку експерименту рівень сформованості естетичної культури був переважно низький і базовий, то з впровадженням педагогічної системи він підвищується. Цьому сприяє иілеспрямована індивідуальна робота викладачів зі студентами, залучення студентів до практичної діяльності в межах естетичного середовища 3ВО, використання інноваційних технологій навчання.

Ключові слова: естетична культура, педагогічний експеримент, педагогічна система, етапи реалізації програми експериментального дослідження, констатувальний та формувальний зрізи, стандартизовані й авторські методики.
\end{abstract}

\section{Valentyna PAPUSHINA, orcid.org/0000-0003-4833-9049 Candidate of Philological Sciences, Associate Professor at the Ukrainian Philology Department Khmelnytskyi National University (Khmelnytskyi,Ukraine) papushyna@ukr.net}

\section{EXPEREMENTAL RESEARCH OF THE PROCESS OF AESTHETIC CULTURE FORMATION OF FUTURE UKRAINIAN LANGUAGE AND LITERATURE TEACHERS}

The article presents the results of an experimental research of the verification of the author's concept and the effectiveness of the developed pedagogical system offormation of aesthetic culture offuture teachers of Ukrainian language and literature in the course of their professional training in higher educational establishments of Ukraine and compliance with a number of pedagogical conditions at the institutional level. Giving the characterizing of the goals and content of the main stages of the experimental study (diagnostic, motivational, methodologically-experimental, analytical and generalizing). There were pointed the standardized and developed author's methods used during the research (M. Rokeach "Valuable orientations", methods of definition of motivation to aesthetic activities of T. Ehlers, questionnaires "The diagnostics of the level of empathy" of I. Yusupov, the reflection questionnaires (by tests of A. Karpov), questionnaires "Defining critical thinking", "Sphere of interests of the students", "Value of aesthetic culture in professional activity of teacher of Ukrainian language and literature", a questionnaire to determine the level of aesthetic perception of works of art 
and their evaluation, interviewing "My aesthetic interests and needs", testing of educational achievements of students). The data of approbation of the pedagogical system in the research period 2012-2019 are presented. In particular, the results of the distribution of future teachers of Ukrainian language and literature on the levels of aesthetic culture formation at the state stage of the experiment and a comparative analysis of the levels of aesthetic culture formation of control and experimental groups before and after it demonstrates the feasibility of using the proposed pedagogical system of formation of aesthetic culture in higher education establishments which train future Ukrainian language and literature teachers. If at the beginning of the experiment the condition of the level of aesthetic culture formation was mostly low and basic, then with the introduction of the pedagogical system it increases. Purposeful individual work of teachers with students, involvement students in practical activities within the aesthetic environment of higher education establishment, using of innovative teaching technologies facilitate to it.

Key words: aesthetic culture, pedagogical experiment, pedagogical system, stages of realization of experiment research, state and formational tests, stale and author's methods.

Випускник ЗВО має бути сформованим як цілісна особистість, усебічно розвинена, здатна до критичного мислення, яка діє згідно з моральноетичними принципами й здатна приймати відповідальні рішення, поважає гідність і права інших, $€$ креативною особистістю, яка змінює навколишній світ за законами краси, конкурує на ринку праці та вчиться упродовж життя. Спрямована на формування естетичної культури майбутніх учителів української мови і літератури організація освітнього процесу «не може бути безсистемною, проводитися застарілими психолого-педагогічними методами» (Зязюн, 1994: 50). Це вимагає розробки ефективної педагогічної системи, яка враховує досягнення педагогічної науки та вимоги сучасного суспільства.

Теоретико-методологічні принципи перевірки ефективності, дієвості та достовірності педагогічної системи, а також організації, проведення та обробки результатів педагогічного дослідження розкрито в роботах С. Архангельського, Ю. Бабанського, В. Безпалька, С. Гончаренка, В. Загвязинського, І. Зязюна, С. Сисоєвої, М. Скаткіна та ін. «Експеримент» (від лат. experimentum - «проба», «досвід», «випробування»), метод пізнання, за допомогою якого досліджуються педагогічні явища, факти, досвід (Скаткін, 1986), дозволить впевнитись у перевагах педагогічної системи i рекомендувати iii до впровадження в вищих навчальних закладах. Ю. Кушнер називає педагогічний експеримент «активним втручанням дослідника в досліджуване ним педагогічне явище з метою відкриття закономірностей і зміни існуючої практики» (Кушнер, 2001: 18). С. Гочаренко, В. Кушнір наголошують на необхідності комплексного вивчення педагогічних процесів, явищ та систем (Гончаренко, 2002). Розроблена нами педагогічна система формування естетичної культури майбутніх учителів української мови і літератури в процесі їх професійної підготовки у ЗВО України та дотримання низки педагогічних умов на інституційному рівні потребує проведення експериментального дослідження.
Метою статті $\epsilon$ висвітлення ходу й результатів перевірки ефективності педагогічної системи формування естетичної культури майбутніх учителів української мови і літератури в процесі професійної підготовки.

Педагогічний експеримент був провідним методом пізнання, за допомогою якого досліджувалося явище формування естетичної культури майбутніх учителів української мови і літератури в процесі їх професійної підготовки у природних умовах естетичного середовища низки українських 3ВО, що здійснюють підготовку таких фахівців. Нами сформульовані мета експерименту та його завдання. Метою експериментального дослідження є підвищення рівня сформованості естетичної культури майбутніх учителів української мови і літератури у процесі їх професійної підготовки, що пов'язано, передусім, із забезпеченням ефективності функціонування педагогічної системи цієї підготовки та дотриманням низки педагогічних умов. Завдання експериментального дослідження полягають у перевірці авторської концепції та ефективності розробленої педагогічної системи формування естетичної культури майбутніх учителів української мови і літератури під час їх професійної підготовки у ЗВО України i дотримання низки педагогічних умов на інституційному рівні. Для реалізації мети експериментального дослідження та забезпечення надійності результатів під час підготовки та проведення експерименту ми спиралися на основні положення теорії та методики проведення експериментальних досліджень. Об'єктом експериментального дослідження є процес формування естетичної культури майбутніх учителів української мови і літератури у 3ВО.

Експериментальні дослідження проводилися поетапно впродовж 2012-2019 рр. Було виділено три етапи реалізації програми експериментального дослідження. Діагностико-мотиваційний eman (2012-2013 pp.) (констатувальний експеримент) проводився на гуманітарно-педагогічному 
факультеті Хмельницького національного університету, факультеті початкової освіти та філології Хмельницької гуманітарно-педагогічної академії, факультетах філології і журналістики Тернопільського національного педагогічного університету імені Володимира Гнатюка, факультеті філології Прикарпатського національного університету імені Василя Стефаника, факультеті української філології Уманського державного педагогічного університету імені Павла Тичини. Для організації методологічно-експериментального emany (2014-2017рр.) педагогічного експерименту було сформовано по дві групи в кожному навчальному закладі: контрольні (КГ) та експериментальні (ЕГ). Контрольні групи із числа студентів першого курсу (2012-2013 рр. набору) загалом склали 144 чоловік, експериментальні - 147. Усього в експерименті брали участь 291 студент названих вище навчальних закладів. На аналітико-узагальнюючому етапі (2018-2019рр.) здійснювалося оброблення та систематизація відомостей, отриманих у ході формувального етапу експерименту, їх порівняння 3 прогнозованими даними, скориговані показники, сформульовано загальні висновки.

Мета діагностико-мотиваційного етапу експерименту - з'ясувати можливості майбутніх учителів української мови і літератури в самореалізації під час навчального процесу, визначити сфери діяльності для кожного 3 них для поглиблення професійних та естетичних знань. На початку першого курсу серед студентів були проведені анкетування (за методикою М. Рокича «Ціннісні орієнтаціï» та за методикою визначення мотивачії до естетичної діяльності Т. Елерса), опитування (опитувальник "Сфера інтересів студентів»), інтерв'ювання («Мої естетичні інтереси ma потреби»). На цьому етапі з'ясовані ціннісні орієнтири студентів на ідеали естетичної культури, потреби та інтереси до формування власної естетичної культури, мотивація до естетичної діяльності студентів-першокурсників, що буде впливати на професійну підготовку та самореалізацію майбутнього учителя української мови і літератури.

Порівняння результатів рівнів сформованості естетичної культури студентів у ЕГ та КГ на діагностико-мотиваційному етапі експерименту проведено за допомогою критерію Стьюдента. Із метою здійснення математичних розрахунків всі обмеження критерію були витримані. Результати сформованості естетичної культури в ЕГ і КГ узагальнено в таблиці (табл. 1).

Як видно з таблиці, низький рівень сформованості естетичної культури студентів значно перевищує високий (ЕГ - 18,9\%, 12, 42\%, КГ - 29,72\% і 7,9\%). Робимо такі висновки:

1. Стан рівня сформованості естетичної культури у студентів досліджуваних груп перших курсів переважно низький і базовий. Для його зростання необхідна цілеспрямована індивідуальна робота викладачів зі студентами, заснована на «добровільному виборі форм діяльності, ініціативі, взаємній довірі» (Загвязинський, 2005: 12).

2. Проводити індивідуальну мотиваційну роботу з першокурсниками, які відмовляються від естетичної діяльності через завантаження фаховими предметами, всебічно сприяти їх входженню до сфери культурно-естетичного середовища 3ВО та поєднання успішного навчання з естетичними потребами.

3. У процесі навчально-виховної роботи використовувати інноваційні технології навчання, інтегративні знання майбутніх учителів української мови і літератури, оскільки «активізація пізнавальної діяльності відбувається за рахунок

Таблиця 1

Результати розподілу майбутніх учителів української мови і літератури за рівнями сформованості естетичної культури на діагностико-мотиваційному етапі експерименту

\begin{tabular}{|c|c|c|c|c|c|c|c|c|c|}
\hline \multirow{3}{*}{$\begin{array}{c}\text { Назва } \\
\text { компонента }\end{array}$} & \multirow{3}{*}{$\begin{array}{c}\text { Назва } \\
\text { критерію }\end{array}$} & \multicolumn{8}{|c|}{ Рівень сформованості } \\
\hline & & \multicolumn{2}{|c|}{ Високий } & \multicolumn{2}{|c|}{ Середній } & \multicolumn{2}{|c|}{ Базовий } & \multicolumn{2}{|c|}{ Низький } \\
\hline & & EГ & КГ & $\mathbf{E \Gamma}$ & КГ & $\mathbf{E \Gamma}$ & КГ & $\mathbf{E \Gamma}$ & КГ \\
\hline & Мотивс & $9,8 \%$ & $11,5 \%$ & $29,9 \%$ & $17,2 \%$ & $31,9 \%$ & $36,8 \%$ & $8,4 \%$ & $34,5 \%$ \\
\hline & Особи & $7,1 \%$ & $5,8 \%$ & $32,1 \%$ & $23 \%$ & $31,6 \%$ & $36,2 \%$ & $29,1 \%$ & $35 \%$ \\
\hline $\begin{array}{l}\text { Ко } \\
\text { лir }\end{array}$ & &, $1 \%$ & $4 \%$ & $32,8 \%$ & $24,1 \%$ & $33,8 \%$ & $47,7 \%$ & $16,1 \%$ & $24,1 \%$ \\
\hline $\begin{array}{l}\text { Діяльнісно- } \\
\text { творчий }\end{array}$ & Праксеол & $15,7 \%$ & $10,3 \%$ & $62,7 \%$ & $39 \%$ & $19,6 \%$ & $25,3 \%$ & $2 \%$ & $25,3 \%$ \\
\hline Середнє значе & & $12,42 \%$ & $7,9 \%$ & $39,37 \%$ & $25,82 \%$ & $29,22 \%$ & $36,5 \%$ & $18,9 \%$ & $29,72 \%$ \\
\hline
\end{tabular}


Папушина В. Експериментальне мослідження процесу формування естетичної кумьтури...

«поєднання» матеріалу, який звичайно викликає низький та високий рівень інтересу» (Зязюн, 2003: 120), залучати студентів до практичної естетичної діяльності.

4. Постійна співпраця зі студентами, контроль зростання рівня естетичної культури кожної особистості, залучення естетичних досягнень студентів до сфери навчального процесу надасть можливість подолати і середній рівень сформованості естетичної культури, відсоток якого доволі високий.

5. Оприлюднення та підтримка творчих здобутків майбутніх учителів української мови і літератури відповідно до їхніх інтересів та нахилів на рівні публікацій, публічних виступів, художньої творчості, сценографії, застосування інформаційних технологій як складових частин навчального процесу сприятиме створенню позитивного емоційного клімату, що впливатиме на зростання рівнів сформованості естетичної культури.

6. Сприяти самореалізації майбутніх учителів української мови і літератури в естетичному середовищі ЗВО, постійно співпрацювати 3 керівниками гуртків, студій, проблемних групи.

На методологічно-експериментальному етапі дослідження в процес професійної підготовки майбутніх учителів української мови і літератури ЕГ було впроваджено розроблені й теоретично обгрунтовані положення, спрямовані на підвищення їх рівнів естетичної культури. Для визначення дієвості запропонованої педагогічної сис- теми застосовувалися такі методи дослідження: тест-опитувальник "Діагностика рівня емпатії» (за І. Юсуповим), опитувальник «Визначення рівня критичного мислення», тест на рефлексію (за опитувальником А. Карпова), опитувальник «Значення естетичної культури у професійній діяльності вчителя української мови $і$ літератури», тестування навчальних досягнень студентів, опитувальник для визначення рівня естетичного сприйняття художніх творів та їх оцінювання.

На аналітико-узагальнюючому етапі педагогічного експерименту на основі використання методів статистичної обробки даних з'ясовано загальний рівень сформованості естетичної культури майбутніх учителів української мови і літератури, здійснено порівняльний аналіз результатів діагностико-мотиваційного й методологічно-експериментального етапів експерименту. Порівняльна характеристика одержаних результатів до та після експерименту засвідчує, що в ЕГ відбулися суттєві зміни в рівнях сформованості естетичної культури, про що свідчить позитивна динаміка їх зростання (табл. 2).

Отже, результати перевірки ефективності педагогічної системи формування естетичної культури майбутніх учителів української мови і літератури в процесі професійної підготовки свідчать про те, що після завершення експерименту в студентів ЕГ помітне зростання високого рівня сформованості естетичної культури, порівняно зі студентами КГ,

Таблиця 2

\section{Порівняльний аналіз рівнів сформованості естетичної культури майбутніх учителів української мови і літератури контрольних та експериментальних груп до та після завершення експерименту}

\begin{tabular}{|c|c|c|c|c|c|}
\hline \multirow[b]{2}{*}{ Рівні } & \multirow[b]{2}{*}{ Критерії } & \multicolumn{2}{|c|}{ Контрольні групи } & \multicolumn{2}{|c|}{ Експериментальні групи } \\
\hline & & $\begin{array}{c}\text { На початку } \\
\text { експерименту }\end{array}$ & $\begin{array}{c}\text { Наприкінці } \\
\text { експерименту }\end{array}$ & $\begin{array}{c}\text { На початку } \\
\text { експерименту }\end{array}$ & $\begin{array}{l}\text { Наприкінці } \\
\text { експерименту }\end{array}$ \\
\hline низький & \multirow{4}{*}{ мотиваційний } & $17(11,57 \%)$ & $13(9,03 \%)$ & $17(11,56 \%)$ & $3(2,07 \%)$ \\
\hline базовий & & $28(19,05 \%)$ & $28(19,45 \%)$ & $28(19,05 \%)$ & $17(11,72 \%)$ \\
\hline середній & & $56(38,10 \%)$ & $59(40,97 \%)$ & $56(38,10 \%)$ & $48(33,10 \%)$ \\
\hline високий & & $46(31,29 \%)$ & $44(30,56 \%)$ & $46(31,29 \%)$ & $77(53,10 \%)$ \\
\hline низький & \multirow{4}{*}{ особистісний } & $20(13,61 \%)$ & $14(9,72 \%)$ & $21(14,29 \%)$ & $1(0,69 \%)$ \\
\hline базовий & & $27(18,37 \%)$ & $25(17,36 \%)$ & $27(18,37 \%)$ & $19(13,10 \%)$ \\
\hline середній & & $56(38,10 \%)$ & $60(41,67 \%)$ & $54(36,73 \%)$ & $48(33,10 \%)$ \\
\hline високий & & $44(29,93 \%)$ & $45(31,35 \%)$ & $45(30,61 \%)$ & $77(53,10 \%)$ \\
\hline низький & \multirow{4}{*}{ гностичний } & $21(14,29 \%)$ & $12(8,33 \%)$ & $19(12,93 \%)$ & $3(2,07 \%)$ \\
\hline базовий & & $29(19,73 \%)$ & $27(18,75 \%)$ & $28(19,05 \%)$ & $16(11,03 \%)$ \\
\hline середній & & $56(38,10 \%)$ & $65(45,14 \%)$ & $55(37,41 \%)$ & $38(26,21 \%)$ \\
\hline високий & & $41(27,89 \%)$ & $40(27,78 \%)$ & $45(30,61 \%)$ & $88(60,69 \%)$ \\
\hline низький & \multirow{4}{*}{ праксеологічний } & $22(14,97 \%)$ & $14(9,72 \%)$ & $20(13,61 \%)$ & $4(2,76 \%)$ \\
\hline базовий & & $27(18,37 \%)$ & $25(17,36 \%)$ & $28(19,05 \%)$ & $14(9,66 \%)$ \\
\hline середній & & $58(39,46 \%)$ & $63(43,75 \%)$ & $55(37,41 \%)$ & $42(28,97 \%)$ \\
\hline високий & & $41(27,89 \%)$ & $42(29,17 \%)$ & $44(29,93 \%)$ & $85(58,62 \%)$ \\
\hline
\end{tabular}


і зменшення низького. Це дозволило впевнитись у перевагах запропонованої педагогічної системи і рекомендувати їі до впровадження у вищих навчальних закладах України. Перспективами подальших розвідок $є$ розроблення методичних рекомендацій студентам та викладачам щодо впровадження педагогічної системи формування естетичної культури майбутніх учителів української мови і літератури в процесі професійної підготовки.

\section{СПИСОК ВИКОРИСТАНИХ ДЖЕРЕЛ}

1. Гончаренко С., Кушнір В. Методологія як важливий складник наукового дослідження в педагогіці. Неперервна професійна освіта: теорія і практика. 2002. Випуск 4(8). С. 15-22.

2. Загвязинский В., Атаханов Р. Методология и методы психолого-педагогического исследования : учеб. пособие для студ. высш. пед. учеб. заведений. Москва : Издательский центр «Академия». 2005. 208 с.

3. Зязюн І. А. Естетичне виховання як об'єкт державної політики / І. А. Зязюн, О. М. Семашко. Вісник Національного університету імені Т. Шевченка. 1994. № 94. С. 49-54.

4. Зязюн І. А. Педагогіка і психологія професійної освіти: результати досліджень і перспективи : збірник наук. пр. / за ред. І. А. Зязюна, Н. Г. Ничкало. Київ : [б.в.]. 2003. 680 с.

5. Кушнер Ю. З. Методология и методы педагогического исследования: учебно-методическое пособие. Могилев : МГУ им. А. А. Кулешова. 2001. 66 с.

6. Скаткин М. Н. Методология и методика педагогических исследований: в помощь начинающему исследователю. Москва : Педагогика, 1986. 152 с.

\section{REFERENCES}

1. Ghoncharenko S., Kushnir V. Metodologhija jak vazhlyvyj skladnyk naukovogho doslidzhennja v pedaghoghici [Methodology as an important component of scientific research in pedagogy] Continued professional education: theory and practice. 2002. Vyp. 4 (8). pp. 15-22. [in Ukrainian].

2. Zagvjazinskij V., Atahanov R. Metodologija i metody psihologo-pedagogicheskogo issledovanija [Methodology and methods of psycology-pedagogical researches]. M.: Akademija. 2005. 208 p. [in Russian].

3. Zjazjun I.A. Estetychne vykhovannja jak ob'jekt derzhavnoji polityky [Aesthetic education as an object of public policy]. Bulletin of Taras Shevchenko National University of Kyiv. 1994. № 94. pp. 49-54. [in Ukrainian].

4. I.A. Zjazjun, N.Gh. Nychkalo. Pedaghoghika i psykhologhija profesijnoji osvity: rezuljtaty doslidzhenj i perspektyvy [Pedagogics and psychology of professional education]. K.: [b.v.]. 2003. 680 p. [in Ukrainian].

5. Kushner Ju.Z. Metodologija i metody pedagogicheskogo issledovanija [Methodology and methods of pedagogical researches]. Mogilev: MGU im. A.A. Kuleshova. 2001. 66 p. [in Russian].

6. Skatkin M.N. Metodologija i metodika pedagogicheskih issledovanij [Methodology and method of pedagogical researches]. M.: Pedagogika. 1986. 152 p. [in Russian]. 